\title{
PRINSIP PERTUMBUHAN ROHANI DALAM EFESUS 5:1-21 DAN KORELASINYA DALAM MENGUPAYAKAN PERTUMBUHAN ROHANI JEMAAT GPDI GUNUNG MORIA BEDAGAI
}

\author{
Tiur Imeldawati ${ }^{*}$, Yayan Erina Br Regar ${ }^{2)}$ \\ ${ }^{1}$ Prodi Pendidikan Agama Kristen, STT Injili Indonesia Medan \\ ${ }^{2}$ Pelayan di GPdI Gunung Moria Serdang Bedagai
}

\begin{abstract}
To live a quality Christian life requires living according to the principles of growth found in the Bible. The spiritual growth of the congregation must be the vision and mission of God's church. The purpose of this research is to find and explain the principles of spiritual growth in Ephesians 5: 1-21 which are still relevant to the principles of spiritual growth; and to explain how to nurture the spiritual growth of the GPdI Gunung Moria Bedagai congregation in accordance with the spiritual growth of Ephesians 5: 121; and to prove that there is a relationship between the principles of spiritual growth in Ephesians 5: 1-21 which correlate with the principles of spiritual growth in the GPdI Mount Moria Bedagai church.
\end{abstract}

Keywords: principle, spiritual growth, GPdI Mount of Moriah

\begin{abstract}
Abstrak
Untuk menghasilkan hidup sebagai seorang kristen yang berkualitas diperlukan hidup sesuai prinsip-prinsip pertubumbuhan yang terdapat dalam Alkitab. Pertumbuhan rohani jemaat harus menjadi visi dan misi gereja Tuhan. Tujuan penelitian ini ialah untuk menemukan dan memaparkan prinsip -prinsip pertumbuhan rohani dalam Efesus $5: 1$ - 21 yang masih relevan terhadap prinsip pertumbuhan rohani; dan untuk menjelaskan cara pengupayaan pertumbuhan rohani jemaat GPdI Gunung Moria Bedagai sesuai dengan pertumbuhan rohani Efesus 5 :1- 21; serta untuk membuktikan adanya hubungan prinsip pertumbuhan rohani dalam Efesus 5 :1- 21 yang memiliki kolerasi terhadap prinsip pertumbuhan kerohanian jemaat GPdI Gunung Moria Bedagai.
\end{abstract}

Katakunci : prinsip, pertumbuhan rohani, GPdI Gunung Moria

\section{PENDAHULUAN}

Beberapa orang Kristen dalam kehidupannya masih belum menyadari dengan benar statusnya sebagai orang percaya, diantaranya ialah pola pikir yang hanya mengarah kepada kuantitas dan kurang memperhatikan kualitas kekristenan. Adalah penting memperhatikan mutu kekristenan dalam kehidupan orang percaya, yang dapat dilihat dari pertumbuhan kerohanian seseorang ke arah yang lebih baik/positif. Prinsip

94 | Korespondensi mengenai artikel dapat dilakukan kepada:

Tiur Imeldawati, STT Injili Indonesia Medan, Jl. Bunga Malem VI Km. 13 Medan Tuntungan

Email: imeltamsar@gmail.com 
pertumbuhan rohani dalam Efesus 5: 1 - 21 masih relevan untuk dilakukan jemaat masa kini dalam meningkatkan kualitas atau mutu kekristenan.

Yang menjadi latar belakang penelitian ini adalah: adanya kecenderungan lalai melaksanakan visi dan misi gereja dan dalam mengupayakan pertumbuhan rohani jemaat. Kedua, Beberapa bentuk pengupayaan pemimpin jemaat GPdI Gunung Moria Bedagai dalam pertumbuhan rohani jemaat namun cenderung belum bertumbuh secara rohani dengan baik dibandingkan dengan usia menjadi Kristen. Ketiga, Hubungan prinsip pertumbuhan rohani jemaat Efesus 5:1-21 dengan pertumbuhan rohani jemaat GPdI Gunung Moria Bedagai dalam pengupayaan yang dilakukan pemimpin terhadap pertumbuhan rohani jemaat sangat berkaitan dan masih relevan diterapkan dalam kekristenan masa kini.

Rumusan masalah Pertama, Apa prinsip pertumbuhan rohani dalam Efesus 5:121? Kedua, Bagaimana mengupayakan pertumbuhan rohani jemaat GPdI Gunung Moria Bedagai sesuai dengan pertumbuhan rohani Efesus 5:1-21? Ketiga, Apakah prinsip pertumbuhan rohani dalam Efesus 5:1-21 memiliki kolerasi terhadap prinsip pertumbuhan kerohanian jemaat GPdI Gunung Moria Bedagai dalam mengupayakan pertumbuhan rohani jemaat GPdI Gunung Moria Bedagai?

Tujuan penelitian ialah Pertama, untuk menemukan dan memaparkan prinsip prinsip pertumbuhan rohani dalam Efesus 5 :1- 21 yang masih relevan terhadap prinsip pertumbuhan rohani. Kedua, untuk menjelaskan cara pengupayaan pertumbuhan rohani jemaat GPdI Gunung Moria Bedagai sesuai dengan pertumbuhan rohani Efesus 5 :121. Ketiga, untuk membuktikan adanya hubungan prinsip pertumbuhan rohani dalam Efesus 5 :1- 21 yang memiliki kolerasi terhadap prinsip pertumbuhan kerohanian jemaat GPdI Gunung Moria Bedagai.

Ruang lingkup penelitian ialah pertama ialah prinsip pertumbuhan rohani jemaat Efesus menurut pasal 5: 1-21 dan kedua ialah jemaat dewasa GPdI Gunung Moria Bedagai yang memiliki usia 17 tahun ke atas dan di kelompokan menjadi orang tua, pemuda dan remaja dan upaya pemimpin jemaat yaitu gembala sidang, sintua, pelayan gereja yang dilakukan dalam meningkatkan pertumbuhan rohani jemaat 


\section{METODE PENELITIAN}

Dalam proses pengerjaan suatu tulisan ilmiah pentingnya dilakukan metode penelitian supaya tujuan dari penelitian tersebut dapat tercapai dan untuk memberi penjelasan dari judul penulisan. Dalam melakukan penelitian ada batasan tempat yang dilakukan, adapun tempat penelitian Gereja Pantekosta di Indonesia (GPdI) Gunung Moria Tanjung Beringin. Metode yang dilakukan ialah metode campuran (Mixed Methods) yaitu penggabungan antara metode kualitatif dan metode kuantitatif. Dalam penelitian ini prinsip - prinsip pertumbuhan rohani dalam Efesus 5: 1-21 sebagai (Variabel Independent) dan pertumbuhan rohani jemaat GPdI Gunung Moria Bedagai sebagai (Variabel Dependent).

Sekilas latar belakang surat Efesus 5:1-21, surat Efesus ditulis oleh rasul Paulus yang ditulis sekitar tahun 60-61 M, surat ini ditulis di Roma ketika pemanjaraannya yang pertama yang dikenal dengan surat penjara dan penulisan surat Efesus hampir bersamaan dengan surat Kolose (Martin, 2012). Surat Efesus ditujukan kepada orangorang percaya dalam Kristus Yesus, surat ini merupakan himbauan dan penekanan kepada penerimanya untuk menekankan rencana Tuhan dan menjadi satu dengan Kristus sebagai kepala, dalam keadaan mereka menyembah kepada dewi Artemis (Duyverman, 1996). Surat Efesus menjadi acuan dalam penelitian ini, dan GPdI Gunung Moria Bedagai adalah lokasi penelitian dilakukan.

\section{HASIL DAN PEMBAHASAN}

Prinsip-prinsip pertumbuhan rohani dalam Efesus 5:1-21 yaitu Pertama, Menjadi penurut Allah. Efesus 5:1 Sebab itu jadilah penurut-penurut Allah, seperti anak-anak

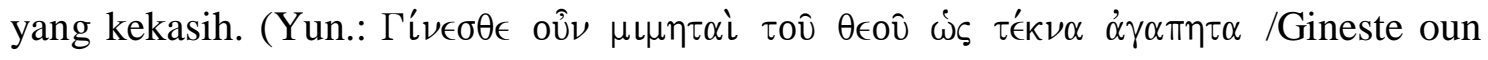
mimetai tou Teou os tekna agapeta). Menurut Van Leeuwen dan Schlier menafsirkan bahwa kata oûv (oun) yang artinya jadi atau karena itu dalam ayat ini memiliki hubungan dengan ayat sebelumnya dan dianggap sebagai rangkuman dari bagian yang lalu tetapi bukan sebagai konklusi (Van Leeuwen Berkelbach, 2015). Rasul Paulus memberikan nasihat supaya menjadi penurut- penurut Allah bagi orang yang mengasihi Allah dalam Kristus, bukanlah hendak menempatkan mereka dihadapan Allah seperti murid-murid dihadapan suatu cita-cita yang harus dicapai melainkan mereka harus 
menjadi penurut-penurut Allah karena mereka telah dikasihi dan dikuduskan oleh Allah (Abbott, 1999). Disimpulkan bahwa menjadi penurut Allah merupakan suatu keharusan bagi setiap jemaat, sebagai penurut sama artinya dengan peniru segala keinginan yang Allah kehendaki untuk dilakukan oleh setiap pribadi.

Kedua, Hidup dalam kasih. Efesus 5: 2 dan hiduplah di dalam kasih, sebagaimana Kristus Yesus juga telah mengasihi kamu dan telah menyerahkan diri-Nya untuk kita

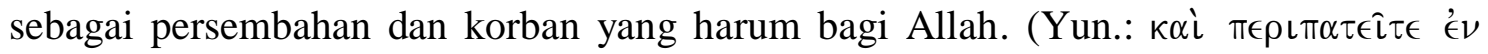

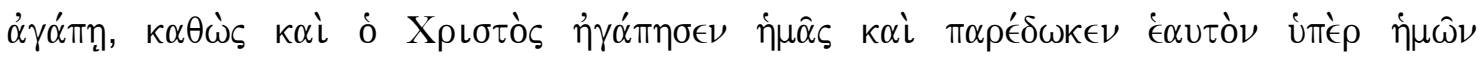

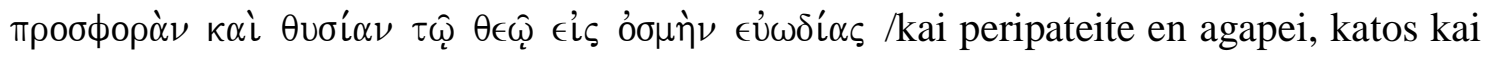
ho Kristos egapesen hemas kai paredoken eauton huper hemon prosforan kai tusian to theos eis osmen euodias). Menjelaskan bahwa kata ini sebagai penurut-penurut Allah tersebut kepentingannya adalah agar mereka hidup dalam kasih, kehidupan dalam jemaat di Efesus harus hidup yang nyaman yang terikat di dalam kasih berdasarkan tata

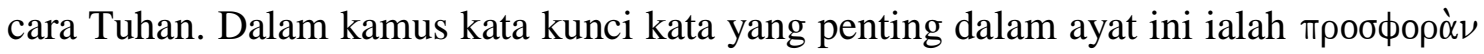

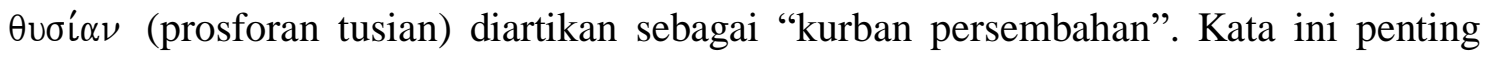
dikarenakan perintah untuk hidup di dalam kasih sudah terlebih dahulu ditunjukan oleh kasih Kristus melalui pengorbanannya sebagai kurban yang berbau harum (B. F. Drewes, 2010). Dapat disimpulkan dalam ayat 1 dan 2 ialah menjadi penurut Allah hal yang dilakukan oleh jemaat Efesus secara terus menerus sebagai anak yang kekasih dalam bentuk penyerahan diri Kristus pada kematiaan untuk umat-Nya menjadi teladan kasih yaitu berkorban.

Hidup dalam kasih harus mampu menjauhi perbuataan dosa. Efesus 5: 3, "Tetapi percabulan dan rupa-rupa kecemaran atau keserakahan disebut sajapun jangan di antara

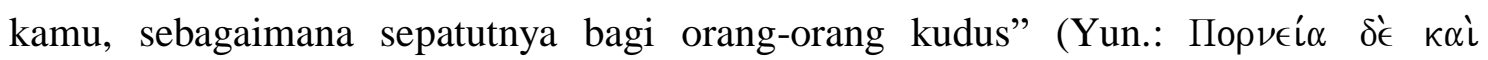

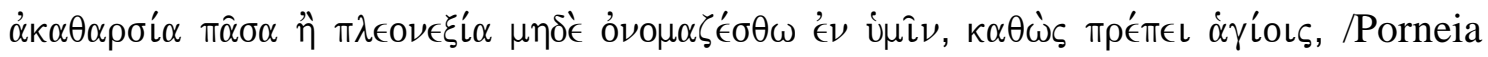
de kai akatarsia pasa e pleonesia unde onomazesto en humin, katos prepei agiois). Bentuk dosa yang sering terjadi dalam jemaat Efesus dan tindakan inilah yang harus dijauhi dalam hidup setiap jemaat, menjadi tolak ukur atau standar yang Allah berikan untuk menjadi penurut Allah. Kesimpulan dari setiap kata penting dalam ayat ini ialah Paulus memulai peringatan baru terhadap sikap yang bertentangan dengan gaya hidup Kristen kembali pada kontras antara komunitas Kristen dan orang yang tidak mengenal 
Allah dan menjauhi kejahatan, pentingnya bagi orang percaya untuk tetap hidup dalam menjaga kekudusan.

Selanjutnya hidup dalam kasih juga harus menjauhi perkataan kosong. Efesus 5:4 Demikian juga perkataan yang kotor, yang kosong atau yang sembrono karena hal-hal

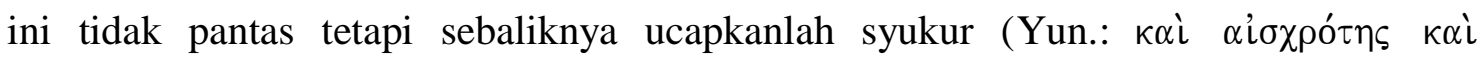

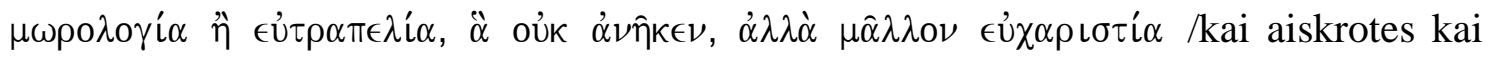
morologia e eutrapelia, a ouk aneken, alla mallon eukaristia). Tujuan dari ayat ini jika melihat kata kuncinya ialah kata kerja fokus kepada permasalahan indikatif kata kerja utama dalam bagian ini supaya jemaat tidak layak mengatakan perkataan yang kotor yang, jadi Paulus terus menerus melarang jemaat Efesus dan menegaskan kepada jemaat yang ada di Efesus agar mereka mempergunakan perkataan yang baik bukan perkataan yang kotor, yang kosong atau yang sembrono melainkan memantaskan diri dengan mengucapkan syukur atas kebaikan yang dirasakan jemaat dalam kehidupan masing-masing.

Dalam Efesus 5:5 Karena ingatlah ini baik-baik: tidak ada orang sundal, orang cemar atau orang serakah, artinya penyembah berhala, yang mendapat bagian di dalam

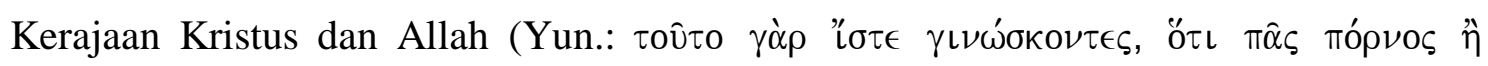

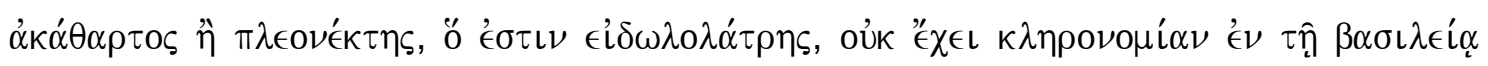

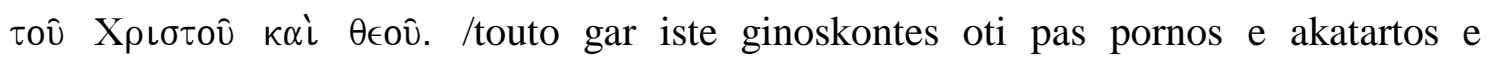
pleonektes, ho eotin eidololatres, ouk ekei kleronomian en te basileia tou Kristou kai Teou). Ayat ini memberikan peringatan akan dampak dari perbuatan yang dilakukan seperti sundal, cemar atau serakah. Kalimat awalan dalam ayat ini dimulai dengan frasa

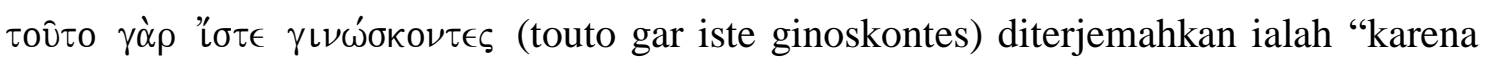
ini kamu ketahui dengan sesungguhnya, insaflah baik-baik, dan ingatlah baik-baik." Hal yang Paulus ingin katakan kepada jemaat Efesus ialah bahwa orang sundal, orang cemar untuk menyerahkan hidupnya ke dalam kebenaran supaya memperoleh keselamatan dalam kerajaan Allah.

Dalam Efesus 5:6 Janganlah kamu disesatkan orang dengan kata-kata yang hampa, karena hal-hal yang demikian mendatangkan murka Allah atas orang-orang

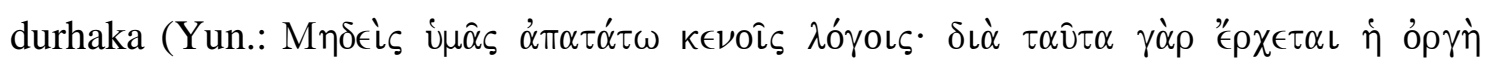




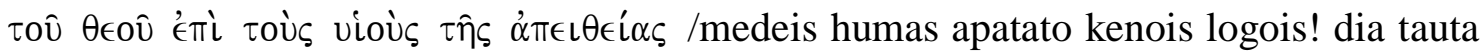
gap erketai he orge Teou epi tous uious tes apeiteias). Kata kuncinya ialah semua orang percaya haruslah memiliki pendirian yang kuat dengan keyakinan yang dimiliki sekalipun akan ada banyak penyesat datang untuk menggoyahkan iman orang yang percaya, melalui kata-kata yang hampa yang artinya tidak ada kebenaran didalamnya dan hal ini akan mendatangkan murka Allah.

Ketiga, Hidup sebagai anak terang yaitu membuahkan kebaikan, keadilan, kebenaran. Efesus 5:8 Memang dahulu kamu adalah kegelapan, tetapi sekarang kamu adalah terang di dalam Tuhan.Sebab itu hiduplah sebagai anak-anak terang (Yun.: $\hat{\eta} \tau \epsilon$

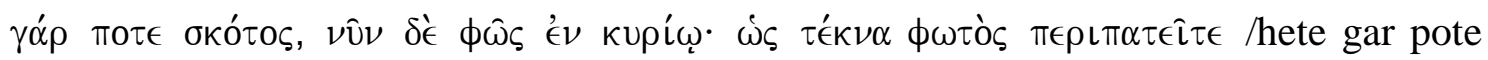
skotos, nun de pos en kurio. hos tekna potos peripateite) Hidup dalam terang mengingatkan bahwa mereka sekarang tidak lagi sama seperti dahulu keharusan bertobat dan menjadi anggota Kristus atau jemaat, kehidupan yang baru dimulai dengan kata terang, yang dahulu kegelapan dan berubah menjadi terang di dalam Tuhan.

Perintah Paulus untuk hiduplah sebagai anak-anak terang, menjelaskan perbedaan antara terang dan gelap antara dahulu dan sekarang, kegelapan yang dimaksudkan ialah hidup dalam pekerjaan suasana dan situasi yang memimpin kepada dosa, namun oleh karena kasih karunia Allah dan jemaat bukan lagi kegelapan melainkan terang yang

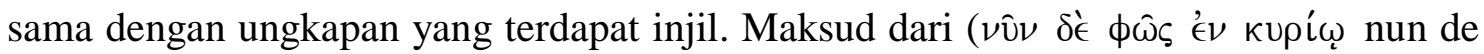
pos en kurio) menyatakan bahwa mereka berada dalam atau diterangi dan mereka adalah terang yang bukan terang dari diri mereka sendiri tetapi terang didalam Tuhan (Abbott, 1999).

Dalam Efesus 5:9 karena terang hanya berbuahkan kebaikan dan keadilan dan

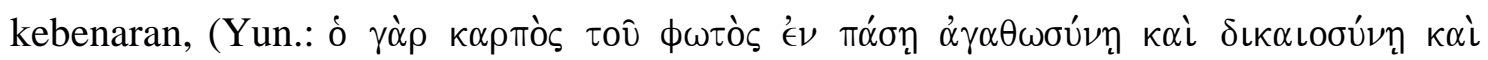
$\dot{\alpha} \lambda \eta \theta \epsilon i \underset{\alpha}{\alpha}$ /ho gar karpos tou kotos en pase agatosune kai dikaiosune kai aleteia). Barclay mengatakan terang itu menghasilkan buah-buah yang baik, yaitu kebajikan, keadilan, dan kebenaran. Kebajikan atau $\alpha \gamma \alpha \theta \omega \sigma u ́ \nu \eta$ (agatosune) adalah jiwa atau semangat

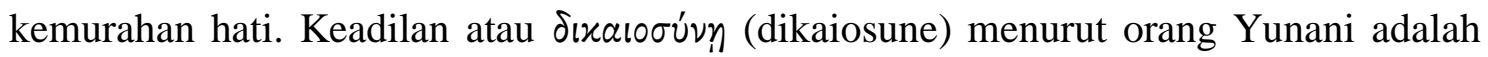
hal memberi kepada manusia dan kepada Allah apa yang menjadi hak mereka. Kebenaran atau $\dot{\alpha} \lambda \eta \theta \epsilon i \alpha$ (aletheia). Setiap orang yang percaya kepada Kristus adalah anak-anak terang. Kesimpulan dalam ayat ini ialah dasar terang di dalam Tuhan mereka 
harus hidup sebagai anak-anak terang merupakan tugas dan panggilan jemaat untuk maksud itulah mereka yang telah dipindahkan dari kuasa kegelapan dan telah ditempatkan ke dalam kerajaan terang.

Mampu menguji kebenaran. Efesus 5: 10 dan ujilah apa yang berkenan kepada

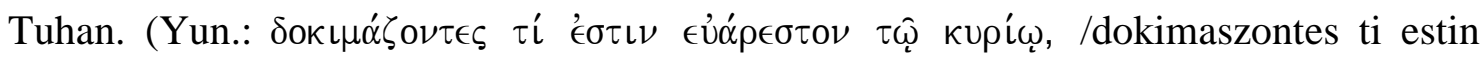
euareston to Kurioi), bertujuan kepada jemaat Efesus untuk menguji situasi keberadaan melalui penyataan Allah di dalam Kristus seperti tertulis ialah dan ujilah apa yang

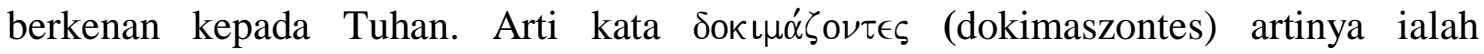
mengambil keputusan, Paulus lebih menekankan bagi jemaat Efesus untuk bertanggung jawab atas perbuatan yang dilakukan sesuai dengan perkenanan Allah, hal yang masih berkaitan dengan hidup sebagai anak-anak terang.

Menelanjangi perbuatan yang jahat. Efesus 5:11 Janganlah turut mengambil bagian dalam perbuatan-perbuatan kegelapan yang tidak berbuahkan apa-apa, tetapi

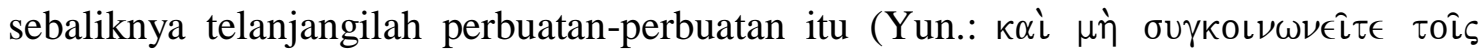

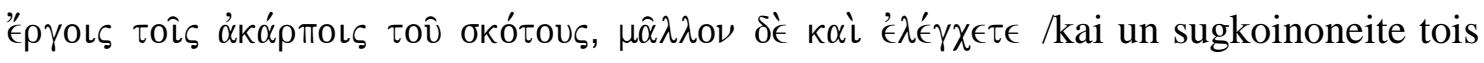
ergois tois akarpois tou skotous, makkon de kai elegkete). Kata penting dalam ayat ini

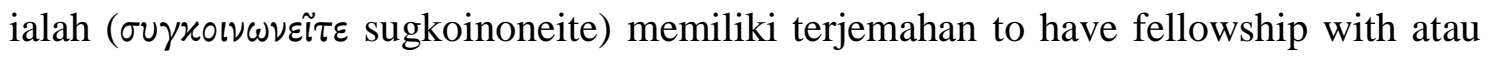
participate, yang apabila diterjamahkan dalam bahasa Indonesia ialah untuk bersekutu atau terlibat dengan. Kata ěpyoı (ergois) memiliki terjemahan "work deed" yang atinya "perbuatan nyata". Kata oxótous (skotous) memiliki terjemahan "darkness" yang artinya "kegelapan” (Maryono, 2016).

Efesus 5: 12 Sebab menyebutkan sajapun apa yang dibuat oleh mereka di tempat-

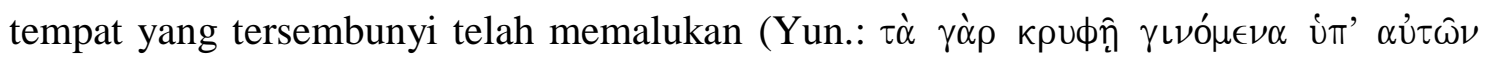

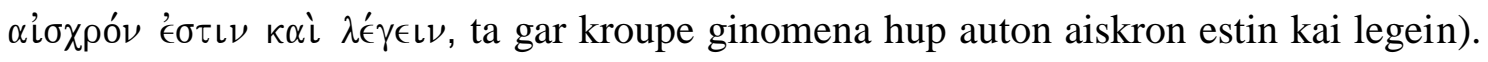

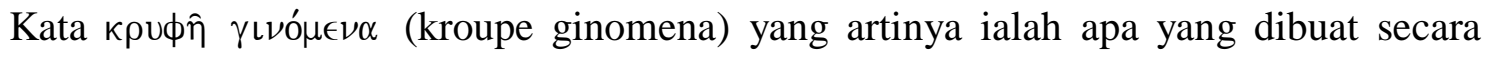

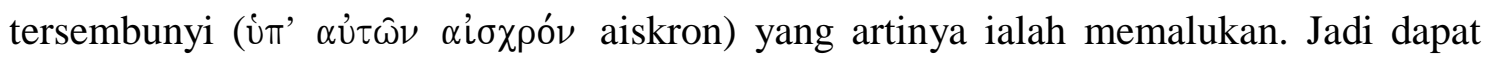
dikatakan bahwa kata menjadi haruslah dilakukan oleh jemaat Efesus. (aioxpóv aiskron) memiliki terjemahan shameful yang apabila diterjamahkan dalam bahasa Indonesia ialah rasa memalukan. ( $\lambda \dot{\varepsilon} \gamma \varepsilon \iota \nu$ legein) memiliki terjemahan to say atau speak yang apabila diterjamahkan dalam bahasa Indonesia ialah berbicara. 
Efesus 5: 13 Tetapi segala sesuatu yang sudah ditelanjangi oleh terang itu menjadi

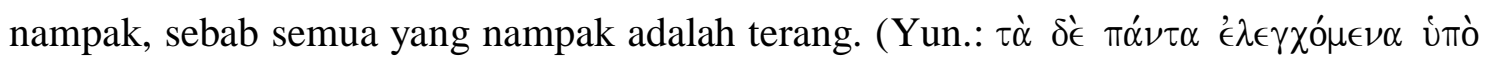

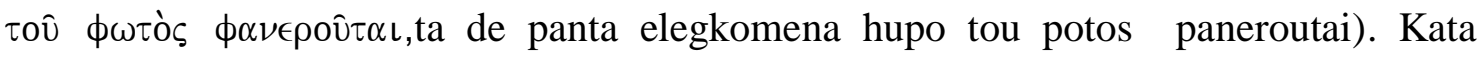
( $\dot{\lambda} \varepsilon \gamma \chi \chi_{0} \mu \varepsilon \nu \alpha$ elegkomena) memiliki terjemahan to convict atau reprove ialah untuk

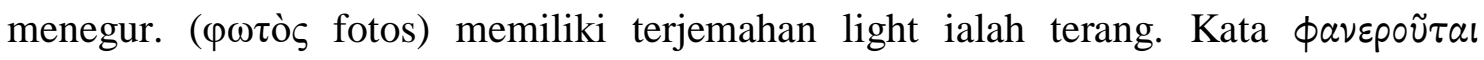
(paneroutai) memiliki terjemahan make manifest reveal ialah menunjukan terang atau nyata bagi setiap jemaat Efesus.

Efesus 5: 14 Itulah sebabnya dikatakan: "Bangunlah, hai kamu yang tidur dan bangkitlah dari antara orang mati dan Kristus akan bercahaya atas kamu" (Yun.: $\pi \hat{\alpha} \nu$

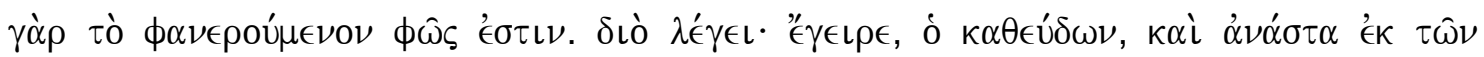

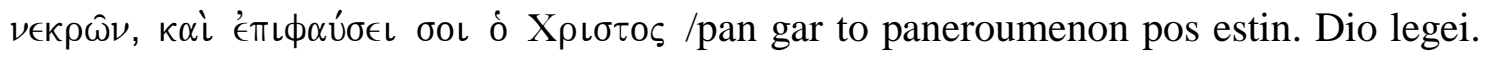
egeire, ho kateudon, kai anasta ek ton nekpon, kai epipausei soi ho Kristos). Ayat ini merupakan nasihat Paulus dari ayat sebelumnya mengenai terang, dalam awalan kata ayat ini ialah $\kappa \alpha \iota$ yang artinya mempertentangkan dengan apa yang dikatakan dalam kedua ayat ini. Sebagai anak-anak terang mereka tidak boleh ikut serta dalam perbuatan kegelapan yaitu hal yang sama dilakukan oleh jemaat Efesus, mempunyai dunia dan suasananya sendiri sama seperti terang menghasilkan dampak, menjauhkan diri dalam arti tidak bergaul dan mereka harus berbuat sebaliknya dengan menelanjangi perbuatan itu (Boice, 1988).

Keempat, Hidup Arif dalam bagian ini Paulus menekankan jemaat Efesus untuk hidup arif atau sering disebut dengan bijaksana yang akan dibagi dalam beberapa bagian bijaksana mempergunakan waktu. Efesus 5:15 Karena itu, perhatikanlah dengan saksama, bagaimana kamu hidup, janganlah seperti orang bebal, tetapi seperti orang

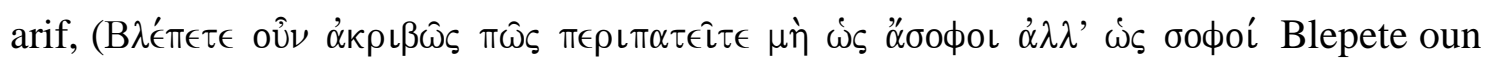
akribos pos peripateite me os asopoi all os sopoi), bagian ini menekankan dengan memulai hidup arif bukan bebal, karena itu mereka tidak boleh hidup sebagai orang bebal melainkan hiduplah sebagai orang yang arif yang memikirkan dan melakukan segala sesuatunya atas dasar kehendak Tuhan.

Efesus 5: 16 "dan pergunakanlah waktu yang ada, karena hari-hari ini adalah

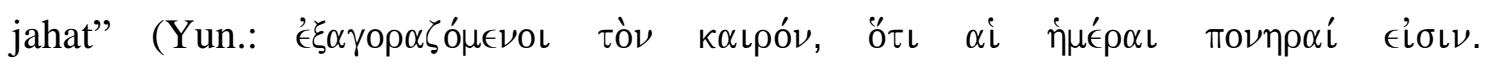
leksagorazomenoi ton kairon, hoti ai hemerai ponerai eisin). Penjelasan dari hari-hari 
jahat ialah hari hari terakhir yang penuh dengan derita dan cobaan atau hari-hari kesukaran, penting memperhatikan waktu dengan waspada dan bijaksana dengan waktu yang ada yang Tuhan. Maksud Paulus dalam hidup mereka di tengah-tengah kuasa yang jahat harus mempergunakan waktu yang ada sehingga kesempatan yang Tuhan berikan kepada mereka, sebagai kesempatan yang akhir, yang baik dan menyelamatkan.

Mengerti Kehendak Tuhan. Efesus 5: 17 "Sebab itu janganlah kamu bodoh, tetapi

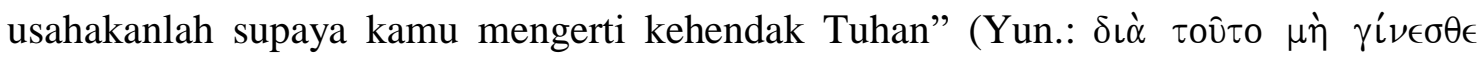

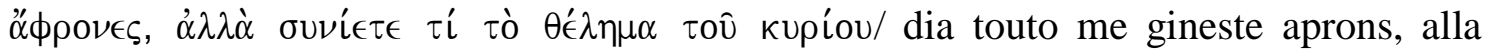
suniete ti to Telema tou kuriou). Ditengah hari-hari yang jahat ini Paulus menekankan kepada jemaat Efesus untuk terus menerus berusaha untuk berusaha mengerti kehendak Tuhan, kehidupan orang arif atau bijaksana mengkehendaki pengertian yang terus menerus mengerti kehendak Allah. Peringatan yang diberikan Paulus kepada jemaat Efesus untuk hidup tidak bodoh tetapi terus berusaha melakukan yang sesuai dengan kehendak Allah, bagian yang menjadikan dasar untuk terus melakukan prinsip pertumbuhan rohani dalam setiap kehidupan orang percaya.

Hidup penuh roh. Efesus 5:18 "Dan janganlah kamu mabuk oleh anggur, karena anggur menimbulkan hawa nafsu, tetapi hendaklah kamu penuh dengan Roh," (Yun.:

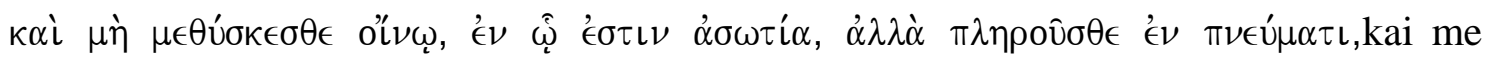
metuskeste oino en oi estin asotia, alla plerouste en pneumati). Kata $\mu \varepsilon \theta \dot{\sigma} \sigma \varkappa \varepsilon \sigma \theta \varepsilon$ (metuskeste) to make drunk ialah "meminum". Frasa olvw (oino) wine dalam bahasa Indonesia ialah anggur. Frasa ḋ $\sigma \omega \tau i ́ \alpha$ (asotia) dissipation debauchery ialah meminum. Kata $\pi \lambda \eta \rho \circ \tilde{\sigma} \sigma \theta \varepsilon$ (plerouste) to fill, fulfill ialah mengisi. Paulus menekankan bagi jemaat Efesus untuk tidak hidup dalam kemabukan oleh anggur melainkan hendaklah hidup oleh Roh.

Efesus 5: 19 “dan berkata-katalah seorang kepada yang lain dalam mazmur, kidung puji-pujian dan nyanyian rohani. Bernyanyi dan bersoraklah bagi Tuhan dengan

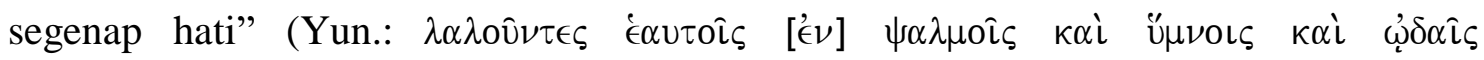

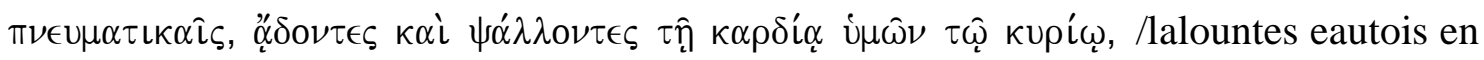
palmois kai humnois kai odais pneumatikais, hadontes kai pallontes te kardia humon to kurio). Sebuah mazmur adalah sebuah nyanyian pujian dan sebuah nyanyian pujian 
adalah sebuah lagu, nyanyian pujian kepada Allah, mazmur seperti sekarang, adalah lagu-lagu religius dan karena itu yang dimaksudkan di sini digambarkan sebagai spiritual mengungkapkan pikiran dan perasaan rohani.

Efesus 5: 20 "Ucaplah syukur senantiasa atas segala sesuatu dalam nama Tuhan

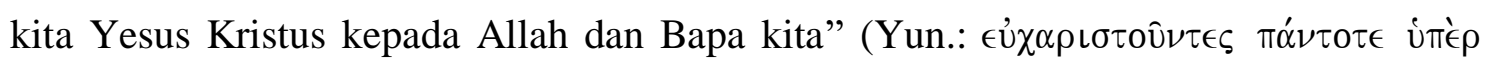

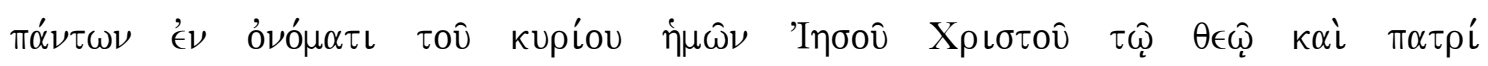
/eukaristountes pantote huper pantone n onomati tou kurion hemon Iesou Kristou to Teo kai patri). Roh yang mempimpin setiap langkah dala hidup sama halnya seperti untuk hidup tidak mabuk anggur dalam arti sebenarnya. Hal lain juga dilakukan dengan mengucap syukur dalam segala hal dan senantiasa, penekanan yang Paulus berikan jemaat yang dipenuhi oleh Roh tidak akan hanya menyanyikan nyanyain pujian kepada Kristus tetapi juga menaikan ucapan syukur secara teratur kepada Allah karena kelimpahan yang diberikan.

Saling merendahkan hati. Efesus 5: 21 "dan rendahkanlah dirimu seorang kepada

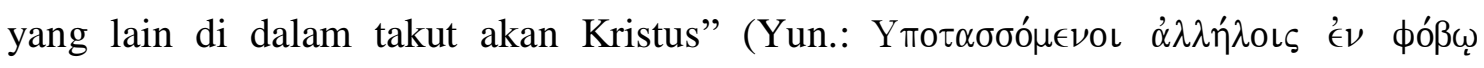

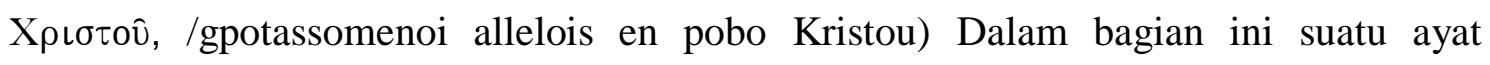
sambungan yang memimpin ke dalam aturan rumah tangga di 5:22, beberapa penafsir menghubungkannya dengan bagian selanjutnya, hidup yang dipenuhi oleh Roh akan ditandai dengan kerendahan hati. Upaya dalam pertumbuhan rohani jemaat Pada dasarnya Allah menghendaki semua orang yang percaya haruslah bertumbuh dewasa dalam hal mengalami pertumbuhan rohani namun pada kenyataannya beberapa orang percaya tetap tinggal sebagai bayi rohani atau masih belum hidup dalam pertumbuhan rohani (The, 2009).

Petama, Membimbing jemaat menjadi penurut Allah umumnya gereja memiliki beberapa usaha dalam membimbing jemaat untuk puncak pertumbuhan rohani khususnya untuk menjadi penurut Allah. Dasar bimbingan rohani adalah membantu kesadaran dan perhatian untuk membawa seorang muda untuk memiliki pengalaman rohani dan menjadi pribadi untuk menghidupi penurut Allah, pembimbingan harus mendorong dan memotivasi jemaat untuk meningkatkan kedewasaan rohani melalui memilki sikap ketaatan akan melakukan firman Tuhan (SJ, 1988). Salah satu langkah dalam membimbing jemaat untuk menjadi penurut Allah ialah dengan pemuridan yang dilakukan untuk setiap jemaat yang mengarahkan kepada kehendak Allah, oleh sebab 
itu jadilah penurut-penurut Allah, seperti anak-anak yang kekasi, dalam pemahaman yang sama mengartikan kata ini menjadi meniru Tuhan dalam memperluas peniruan (Best, 1998).

Kedua, Membimbing jemaat untuk hidup dalam kasih dengan melihat kasih Tuhan yang terlebih dahulu diberikan melalui pengorbanan Kristus yang menjadikan dasar bagi semua orang untuk terus mengasihi Tuhan dalam hidup karena Tuhan yang terlebih dahulu mengasihi kita. Pelayanan konseling merupakan salah satu bagian dari pelayanan hamba Tuhan, dan akan kehilangan identitasnya jikalau ia menolak tugas pelayanan yang ini. Meskipun demikian pelayanan konseling bukan pelayanan yang secara otomatis dapat dilakukan hanya karena bakat alamiahnya dalam pengembalan ataupun oleh karena kuliahnya teologia, dikarenakan pelayanan konseling merupakan inti pelayanan seorang hamba Tuhan. Pentingnya melakukan pelayanan konseling dikarenakan pelayanan ini dipercayakan oleh Allah sendiri yang mutlak bergantung pada Roh Kudus, didasarkan pada firman Tuhan (Susabda, 2012).

Ketiga, Mengajar jemaat untuk hidup dalam terang upaya yang dilakukan oleh pemimpin gereja dalam memberikan pertumbuhan rohani jemaat penting sekali dilakukan suatu proses pengajaran. Mengajar merupakan seni, yaitu suatu hal yang dimuncul dengan sendirinya yang menjadikan daya tari tersendiri, secara umum semua orang sudah bisa membedakan mana yang baik dan yang tidak baik atau mengerti dosa atau tidak. Hal inilah yang harus diperhatikan pemimpin gereja untuk membangun pertumbuhan rohani jemaat dalam memiliki sikap untuk menjauhi perbuatan dosa dan hidup semakin memuliakan Tuhan, konseling yang berfokus pada pribadi menekankan emosional kita sebagai sumber pemahaman bagi pikiran, perasaan, dan tindakan kita (Gondowijoyo, 2005).

Keempat, Mengajar jemaat hidup bijaksana, dalam bagian terakhir sebagai bentuk prinsip-prinsip pertumbuhan jemaat dijelaskan semua jemaat haruslah memiliki sikap bijak, bijak yang dimaksud dalam arti mengenal diri sendiri dan Allah seperti apa adanya Dia akan menghubungkan kita dengan rancangan kekal dari Pribadi yang menciptakan kita (Leigh, 2011). Mengajar jemaat untuk hidup dalam kebijaksanan memerlukan sikap menjadi penurut Allah dan tetap hidup dalam terang menjauhi 
kejahatan pentingnya memiliki sikap yang sesuai dengan pengajaran seperti mampu menggunakan waktu sebaik mungkin, tetap hidup didalam roh yang selalu mengingatkan akan kesalahan atau perbuatan yang tidak sesuai. Mengajarkan dan mendorong jemaat untuk terus berusaha membaca Alkitab dan jam doa dan waktu saat, rajin membaca Alkitab dan mengetahui kehendak Allah yang akan membuat jemaat sebagai penurut Allah.

\section{KESIMPULAN DAN SARAN}

Hasil temuan penelitian merupakan hubungan murni antara $\mathrm{X}$ dan $\mathrm{Y}$ dalam penelitian ini sebesar $67 \%$ dengan arti prinsip-prinsip pertumbuhan rohani dalam jemaat Efesus 5:1-21 dan kolerasinya dalam pengupayaan prinsip pertumbuhan rohani jemaat GPdI Gunung Moria berada pada level kuat dan terdapat 33\% lagi oleh upayaupaya yang tidak dibahas dalam penelitian ini.

Pertama, prinsip pertumbuhan rohani dalam jemaat Efesus 5:1-21 di bagi menjadi beberapa bagian yaitu hidup menjadi, hidup dalam kasih, hidup sebagai anak terang, dan hidup arif. Kedua, bentuk pengupayaan yang dilakukan oleh pemimpin jemaat GPdI Gunung Moria Bedagai atau gembala dalam pertumbuhan rohani adalah dengan melakukan membimbing jemaat menjadi penurut Allah dengan memberikan pengajaran untuk melakukan perintah Allah, membimbing jemaat untuk hidup dalam kasih seperti kasih yang diajarkan Kristus melalui pengorbanan, mengajar jemaat untuk hidup dalam terang, dan mengajar jemaat untuk hidup arif atau arif.

Ketiga, Variabel antara X dan Y dalam penelitian ini sebesar 67\% dengan arti pengaruh murni dalam prinsip-prinsip pertumbuhan rohani dalam jemaat Efesus 5:1-21 dan kolerasinya dalam pengupayaan prinsip pertumbuhan rohani jemaat GPdI Gunung Moria berada pada level kuat dan terdapat 33\% lagi oleh prinsip-prinsip yang tidak dibahas dalam penelitian ini.

Saran penulis bagi gembala adalah untuk lebih sungguh-sungguh lagi dalam mengajar jemaat dan menerapkan kebenaran Alkitab, sekaligus tetap menjadi teladan dalam melakukan firman Allah. Saran bagi jemaat dan para pelayan adalah untuk bekerjasama dengan gembala, sehingga semakin bertambah hari-hari, semakin terlihat pertumbuhan rohani jemaat sebagia orang Kristen, dan bisa menjadi berkat bagi masyarakat. 


\section{UCAPAN TERIMAKASIH}

Ucapan terima kasih yang besar disampaikan kepada gembala dan seluruh jemaat GPdI Gunung Moria Bedagai, atas kesempatan yang diberikan untuk melakukan riset di gereja tersebut, dan mendapatkan temuan penelitian. Terima kasih juga kepada tim Jurnal Christian Humaniora IAKN Tarutung.

\section{DAFTAR PUSTAKA}

Abbott, T. K. (1999). A Critical and Exegetical Commentary on the Epistles to the Ephesians and to the Colossians. C. Scribner's sons.

B. F. Drewes, D. (2010). Kunci Bahasa Yunani Perjanjian Baru Surat Roma Hingga Wahyu. BPK Gunung Mulia.

Best, E. (1998). A Critical and Comentary on Ephesians. T \& T Clark International.

Boice, J. M. (1988). Ephesians: An Expositional Commentary. Ministry Resources Library.

Duyverman, M. E. (1996). Pembimbing Ke dalam Perjanjian Baru. BPK Gunung Mulia.

Gondowijoyo, J. H. (2005). Membangun Manusia Rohani. ANDI OFFSET.

Leigh, R. W. (2011). Melayani Dengan Efektif. BPK Gunung Mulia.

Martin, R. P. (2012). Tafsiran Alkitab Masa Kini Jilid 3. Yayasan Komunikasi Bina Kasih.

Maryono, P. (2016). Gramatika Dan Sintaksis Bahasa Yunani Perjanjian Baru. Iman Press.

SJ, C. M. S. (1988). Menuju Kedewasaan Rohani Kristen. Kanisius.

Susabda, Y. B. (2012). Pastoral Koseling. Gandum Mas.

The, J. (2009). 10 Prinsip yang Membawa Anda Mencapai Kedewasaan Rohani yang Maksimal: Reach To The Highest. ANDI OFFSET.

Van Leeuwen Berkelbach, D. (2015). Tafsiran Alkitab Surat Efesus. BPK Gunung Mulia. 